\title{
Arabicization of Business Terms from Terminology Planning Perspective
}

\author{
Fawwaz Al-Abed Al-Haq ${ }^{1} \&$ Sarah A. Al-Essa ${ }^{2}$ \\ ${ }^{1}$ Tafila Technical University, Tafila, Jordan \\ ${ }^{2}$ English Language and Literature Department, The University of Jordan, Amman, Jordan \\ Correspondence: Fawwaz Al-Abed Al-Haq, Tafila Technical University, Tafila, Jordan. E-mail: \\ Fawazm57@gmail.com \\ $\begin{aligned} & \text { Received: November 18, } 2015 \\ & \text { Accepted: December 10, } 2015 \quad \text { Online Published: January 31, } 2016 \\ & \text { doi:10.5539/ijel.v6n1p150 }\end{aligned} \quad$ URL: http://dx.doi.org/10.5539/ijel.v6n1p150
}

\begin{abstract}
The main purpose of this study was to measure the extent of acceptability of Arabicized business terms. The present study investigated the attitudes of business students toward the Arabicization of business terms. Besides, it drew attention to the criteria of acceptability to be taken into consideration in the Arabicization process to produce acceptable business terms. Finally, it brought into focus the role of gender, university affiliation, and specialization in the Arabicization process of business terms. A total of two hundred questionnaires were distributed to business students at the University of Jordan and Yarmouk University. It has been found that Arabicized business terms were moderately accepted by the users. Overall, users' attitude toward Arabicized business terms was somewhat positive. Gender and university affiliation variables had influence on these criteria. Like the specialization variable, they caused different attitudes toward these terms. Enthusiasm toward the idea of Arabicization because of pan-Arab identity was strong. This study could be useful for Arabicization decision makers to get acceptable Arabicized business terms. It is the first step towards enhancing understanding of gender role in the Arabicization process. This study also has implications for further research into the importance of Arab nationalism in promoting Arabicized terms.
\end{abstract}

Keywords: Arabicization, business terms, terminology planning, acceptability

\section{Introduction}

Arabicization and terminology planning in translation have received much attention over the last two decades. Terminology planning will inevitably be one of the critical issues in translation due to ongoing developments in all fields of science and continuing need for coining new terms.

The major issue in this study is measuring the degree of acceptability of some problematic Arabicized business terms. Measuring the degree of acceptability is based on these criteria of acceptability: Knowledge, evaluation, usage, adoption, and proficiency (Cooper, 1989).

The researchers investigate the attitudes of business students toward the Arabicization of business terms, solving the problems which would be as an obstacle in the way of Arabicization decision makers. The present study also sheds light on the problem of producing acceptable terms taking into consideration the criteria of acceptability in the process of Arabicization of business terms.

The central questions to be dealt with in this study are as follows:

1) To what extent are the Arabicized business terms acceptable?

2) To what extent are the five criteria of acceptability (knowledge, usage, evaluation, adoption and proficiency) influenced by gender, university affiliation, and specialization?

3) What are the attitudes of business students toward the idea of Arabicization and the work of the Jordan Academy of Arabic?

The present study brings into focus the criteria for measuring the acceptability of Arabicized business terms, hence, it paves the way for Arabic language academies in Jordan and the Arab world to produce acceptable terminology. As a result of this, the major significance of this study lies in its attempt to refresh and revitalize the literature of term planning not only in Jordan but also in the Arab world as a whole by presenting the acceptable 
business terms to the academies.

Previous studies have not addressed the issue of Arabicization of business terms from a terminology planning perspective. They ignored the issue of Arabicization in business. The Jordan Academy of Arabic has not published a separate pamphlet for Arabicized business terms like it did with terms in other fields. This study is the first step toward providing Arabic with acceptable and unified business terms that would help translators in rendering foreign business texts in Arabic. The present study also brings into focus the roles of gender, university affiliation and specialization they play in the Arabicization process. This aids decision makers in the Arabicization process and enables them to produce acceptable terms.

This study is divided into five main sections. In the first section, the problem of the study is stated and its significance is clarified. In the second section, the review of related literature and the definitions of key terms are presented. The methodology is outlined in the third section. The fourth section shows the results of the study. Also, the results are discussed in the same section. Finally, conclusions and recommendations are drawn in the fifth section.

\section{Definitions of Key Terms and Literature Review}

\subsection{Preface}

Terminology is basically a study that deals with "names" and "naming" activities (Rey, 1995: 11). Originally, the word "nomenclature" which appeared in French and English at the beginning of sixteenth century was used by the speakers before the usage of the word "terminology" (ibid, 1995).

In the twentieth century, English dictionaries included the meaning of the word "terminology" in the sense we utilize these days (ibid, 1995). According to The Concise Oxford Dictionary of Current English (1919, p. 911), "terminology" is a "science of proper use of terms". Regarding the word "term", Al-Khuri (2001) argues that the term is a word which has a new meaning that is different from its original denotative meaning and it is utilized in scientific contexts in a specific field of study.

In the literature, other definitions of "terminology" and "terminology planning" can be found. Sager (1990, p. 3) distinguishes three meanings for the word "terminology". The first one is concerned with the series of activities and procedures in which the terms are gathered, defined, explained, and represented. The second one is related to the relationship between the "concepts" and the "terms" which is clarified through a series of hypotheses and conclusions. The third one defines "terminology" as the set of lexical items in specific field of study.

Emran (1993, p. 170) defines terminology as "a scientific and technical discipline which is concerned with the profound study of scientific terms in specific scientific and technical fields regarding the concepts, naming these concepts, standardizing and unifying them." (The translation is mine.).

The International Information Centre for Terminology (Infoterm) (2005, p. 8) defines terminology as groups of terms -used only in a specific field of study.

Could these groups of terms be set arbitrarily? Are there any steps needed to be taken in order to coin them? Who are the persons or the parties responsible for planning terminology?

\subsection{Terminology Planning}

Terms cannot be set arbitrarily. There has to be coordination between language academies, translators, planners, linguists and scientists to coin new terms in different fields on a linguistic basis. Since every language has its own nature which is different from other languages, what is acceptable in one language could not be adequate for another one. Accordingly, terminology planning is an organized activity which revives languages and provides them with new scientific terms to protect them from death.

According to AL-Abed AL-Haq (1998a, p. 8), terminology planning is a three-stage activity. The first stage is a linguistic one which he (ibid) calls "corpus term planning". It is the formation of new terms by following word formation procedures. It also refers to the activities of modifying the terms or selecting specific terms. The second stage is concerned with the authorization of terms by the bodies which have power, such as governments, and by giving each term a particular meaning for a specific aspect of life. This stage is also concerned with extending the uses of terms, restricting, or maintaining them. AL-Abed AL-Haq (1998a, p. 8) calls the last stage "acquisition term planning". It refers to the activities of teaching the terms and learning them.

Al-Abed AL-Haq (1998a) suggests that language planning and terminology planning are closely related to each other. He argues that terms are part of the language, and what is attributed to language is also attributed to terms. Accordingly, what is related to language from planning perspective is also related to term planning. 
Infoterm (2005) distinguishes between language planning and terminology planning. Terminology planning activities cannot be implemented without the presence of previous linguistic base while language planning activities create this linguistic base. (Infoterm, 2005).

\subsection{Guidelines for Terminology Planning}

\subsubsection{Terminology Planning and Technology}

Since technology affects all aspects of life these days, planners should take advantage of technology for refreshing language and providing it with new terms by taking advantage of available technological tools and software.

Technology plays a vital role in facilitating and organizing the work of language and term planners and translators. Sager (1990, p. 88) suggests that technology contributes in paving the way for gathering and spreading new terms to avoid terminological inconsistency phenomenon which leads to misinterpretation, confusion and deformation of terms. He also argues that technology helps in spreading the industrial terminology as it develops through organized collecting of terms. Technology is also important in designing the terminology needed for writing and documenting using software which are suitable to do so. Consequently, the terminological consistency in writing documents and translating them will be guaranteed.

Terminology management systems are computer programs which are used to input, "store, process and output" the terms by following standardized "professional principles" (Infoterm, 2005, p. 3).

\subsubsection{Criteria of Acceptability of a Translated Term}

The International Organization for Standardisation (ISO) has provided worldwide guidelines for word formation that is suitable for all languages. They are listed in ISO document R 704 (Naming Principles). They could be summarized as follows (Sager, 1990, p. 89):

a) Terms should not be created arbitrarily. They should conform to the language in which they are created morphologically, syntactically, semantically and pragmatically.

b) Terms should follow the phonological and morphological characteristics of the language in which they are created. They should also follow its spelling conventions.

c) When the terms become widely accepted by their users, they should not be changed without persuasive reasons and strong certainty that the new terms will be fully accepted as alternatives.

d) In case that a term becomes a partial substitute of an old one, a new term should be coined to avoid terminological inconsistency and confusion.

Al-Sayadi (1980) focuses on the brevity and accuracy of the term so as to be accepted by users. AL-Abed AL-Haq (1998a) also focuses on the conciseness of the term to be accepted. Khalifah (1987) believes that the things which control the spread or the death of a term are: adopting a term by the speakers, spreading it, and passing of the time.

The conditions needed for a term to be accepted by the users as Sager (1990, p. 89) believes could be summarized as follows:

a. There should be a logical relationship between the term and the concept it refers to.

b. The term should conform to an existing lexical system and follow the transcription system of the language in which it is created.

c. The rules of word-formation of the language should be followed when coining a new term.

d. The term should be a derivative.

e. The term should not constitute redundant repetition by having within the same term a foreign word with a native one in which both have the same meaning.

f. The term should be precise and concise.

g. The term should not have synonyms, homonyms, or morphological variants.

Sager (1990, p. 13) argues that the theory of terminology can be examined from three dimensions: "cognitive", "linguistic" and "communicative" dimensions. The "cognitive dimension" examines the relationship between the linguistic structure of the terminologies and their intangible contents. The "linguistic dimension" investigates the representation of these abstract contents in language. Finally, "communicative dimension" studies the usage of these terminologies and the way of organizing them.

\subsection{Arabicization}

Arabicization is an inevitable need for the Arabic language to protect it from death and to enrich it with new words. 
Accordingly, organizing Arabicization process is a necessity to protect the Arabic language from death.

AL-Abed AL-Haq (1998b) differentiates between Arabicization and Arabization. Arabization is derived from the word "Arab". Thus, it refers to Arab culture and people and it has nothing to do with language. On the contrary, Arabicization which is the word he opts for in his studies of terminology and language planning is derived from the word "Arabic". Thus, it is something that has to do with lexis and lexical items in Arabic. Accordingly, he uses it when referring to Arabic language planning. In the present study, the researchers opt for the word Arabicization for the same reason.

El-Khafaifi (1985, pp. 151-152) identifies two different meanings for Arabicization. The first one shows Arabicization from grammarians' point of view where foreign words are embedded in Arabic language. The second definition refers to the derivative strategies used in producing new Arabic words to refresh the literature of terms in Arabic language and to enable it to be effectively used in all types of communication in all realms of study.

According to Balasi (1988, p. 137), Arabicization is the "uttering of foreign words by Arabs according to their methods and ways." (The translation is mine)

Al-Alami (1990, p. 160) concludes that Arabicization as agreed on by the researchers in this field is "to find an Arabic equivalent for a foreign word which does not have an Arabic equivalent...” (The translation is mine.)

Al-Baba (1995, p. 30) distinguishes between two definitions for Arabicization:

The first one is to borrow a foreign term and make it suitable for Arabic letters and morphology. The second one is to create Arabic terms by translation, derivation, or compounding in order to coin Arabic equivalents for foreign terms. (The translation is mine.)

According to al-Qurashi (1982, p. 32), foreign terms have to cope with Arabic phonologically and morphologically to become Arabicized. Thus, phonological and morphological conventions of Arabic should be taken into consideration when Arabicizing new terms.

For Abed Al-Aziz (1990), Arabicization has two facets. The first one is the phonological transferring of the words into Arabic. The second one is the translation of the words in which the foreign words are semantically transferred into Arabic. He also believes that these facets are interdependent.

Since Al-Didawi (2007, p. 78) considers that translating into Arabic is the same as Arabicization, he combines Arabicization and translation in one term, namely "Arabicized translation". He defines Arabicized translation as rendering ideas into Arabic by summarizing the original text in the target language, and simplifying it to the readers, having the right to change it without affecting its meaning. Summarizing foreign scientific research in Arabic is an example (Al-Didawi, 2007, p. 78).

Like Jaied (2010), Farghal (2012) regards Arabicization as a strategy of translation. He argues that whenever the translator comes across new terms, he may borrow terms from other languages, making them suitable morphologically and phonologically to Arabic language.

\subsubsection{Arabicization Planning}

A non-organized Arabicization activity may cause ambiguity to Arabicized terms. This may confuse the users of the terms when coming across the floods of terms produced for the same foreign term. Therefore, standardizing the Arabicized terms is a basic need for the success of Arabicization planning activities. This may also facilitate going over the problem of synonomy in Arabic language which emerges from inaccurate choosing of non-organized Arabicized terms.

According to AL-Abed AL-Haq (1998b, pp. 59-60), Arabicization planning has three-stages. The first stage is a linguistic one which he (ibid) calls "corpus Arabicization". It includes coining new terms and adopting new scientific symbols. It also refers to issues related to the spelling conventions of Arabic language. The second stage is concerned with the authorization of the Arabicized terms by bodies which have power over the users such as governments. This stage is called "status Arabicization" AL-Abed AL-Haq (1998b, p. 59). AL-Abed AL-Haq (1998b, p. 59) calls the last stage "Acquisition planning of Arabicization". It refers to the activities of teaching the Arabicized terms and learning them. This stage also includes the spread of Arabic language and accepting the idea of Arabicization.

Abu-Abdo (1984) suggests many recommendations for Arabicization to be in its right way. He proposes some procedures such as fighting illiteracy and teaching Arabs the standard Arabic, standardizing Arabicized terms in all fields, making a law for Arabicization, and raising public awareness regarding the importance of Arabicization. The previous points embody the last two processes of Arabicization suggested by AL- Abed AL-Haq (1998b). On 
the other hand, Abu-Abdo (1984) recommends not translating foreign phrases literally, avoiding colloquial words, trying not to use archaic words which aim at showing off, but trying to utilize common ones. These points exemplify the corpus Arabicization suggested by AL-Abed AL-Haq (1998b).

\subsection{Previous Empirical Studies}

Arabicization and terminology planning have been the topics of focus by many researchers in the Arab countries and in Jordan. These studies helped in making Arabic language able to deal with the flood of new terminologies in different subject areas. In the following studies, the terms "Arabicization" and "Arabization" are used interchangeably.

Halloush (2000) investigated Arabicization of medical terms from language and term planning perspectives. The results of her study showed that the majority of physicians did not accept the Arabicized medical terms. Besides, they thought that there was no need to the Arabicization of medical terms. Furthermore, they thought that the work of the Jordan Academy of Arabic was poor and not organized.

AL-Qahtani (2000) discussed Arabicization as a "quasi ideological-linguistic phenomenon". He concluded that Arabicization in Saudi Arabia suffered from the absence of cooperation between language academies in the Arab world, the absence of a defined means for implementing Arabicization, and the lack of evaluation of the real usage of suggested Arabicized words. He pointed out to the frequency of using Arabicized words in written discourse in Saudi Arabia. He reached the conclusion that there was a relationship between the context and the frequency of using Arabicized terms. Arabicized terms were used more frequently in scientific texts than in religious and literary ones. He also argued that translating scientific terms literally without checking the Arabicized equivalent of the source foreign term was a problem from which Arabicization suffered.

Mahasneh (2002) evaluated the translations of internet terms from language and term planning perspectives. She ended by the conclusion that computer students did not accept the Arabicized equivalents of foreign internet terms. Moreover, their attitude toward Arabicization was negative. In other words, they were not willing to accept Arabicization processes. Furthermore, they thought that the work of the Jordan Academy of Arabic needed to be reformed and promoted since the academy has not listed Arabicized equivalents for internet terms at that time.

AL-Sakran (2004) tackled the issue of Arabicization of agricultural terms from a terminology planning perspective. She concluded that most of agricultural students had positive attitudes toward Arabicization. The Arabicized agricultural terms by the Jordan Academy of Arabic were moderately accepted by the users. However, they called for the Arabicization of some agricultural terms again to be accepted by their users. They also called for reformation in the Arabicization mechanisms followed by the Jordan Academy of Arabic.

El-Fadni (2004) examined the attitudes of language users, policies and conflict toward the Arabicization of the curricula of medicine at the universities in Sudan. He concluded that most of students had positive attitudes toward learning medicine in Arabic. However, they did not accept marginalizing English language from using it as a medium of instruction in teaching medicine because they thought that they needed to know English as an important requirement for practicing medicine in the future. They preferred to use a mixture of Arabic and English in their studying.

Hawamdeh (2004) conducted a study which investigated the acceptability of using different word formation methods in translating weather terms. One of these methods was Arabicization. The results of the study revealed that the methods of coining new words in Arabic were familiar to the most of the specialists. The study also indicated that the pamphlet of weather terms published by the Jordan Academy of Arabic was not commonly used in translation because the translators while rendering weather terms depended on different specialized dictionaries and their general knowledge. In this study, the specialists, the students, and the translators used different synonyms for the same concept. Thus, the researcher called for unified and consistent terms by producing a unified dictionary for weather terms. Depending on the results of the study, knowledge, competence, and practice were the requirements to produce a precise translation.

AL-Abed AL-Haq \& Al-Masaeid (2009) investigated language planning in Jordan in light of the attitudinal trends of university students toward language planning. They concluded that language planning was ideologized. In other words, it was affected by religion and cultural orientations. According to them, the reason behind defending Arabic was that Arabic is the language of Islam and Quran. They concluded that learning English did not mean adopting western culture and did not mean marginalizing the culture of Islamic civilization. However, learning English opened the doors for a future full of opportunities of education and business.

Al-Asal \& Smadi (2012) measured the frequency of using Arabicization and Arabic expanding techniques by faculty members in their scientific lectures in Jordan University of Science and Technology (JUST) and in the 
University of Damascus (UD). The results of the study showed that Arabicization was utilized in JUST more than in UD. Nevertheless, Arabic expanding techniques, i.e., derivation, compounding, loan translation, semantic extension etc. were used more frequently in UD than in JUST. In their study, the researchers drew attention to the necessity for a solid basis of coordination between Arabic language academies to overcome the problem of synonomy and to standardize scientific terms.

Qoqazeh (2013) measured the acceptability of the Arabicization of ophthalmology terms done by Al-Lisan Al-Arabi Journal. She also investigated the attitudes of the specialists and students toward Arabicization and the feasibility of the efforts made by the journal. She concluded that the majority of specialists and students did not accept the Arabicized terms suggested by the journal and they had negative attitudes toward the Arabicization of ophthalmology terms and the work of the journal.

The present study tackles the issue of Arabicization of terms in an important common subject field which is embedded in every industry in our life. This field of study has not been covered before. The majority of previous studies focused on investigating the terms in scientific fields of study ignoring the terms in humanities specializations. Thus, this study is the first step toward calling the Jordan Academy of Arabic and the researchers to pay more attention to the terms in humanities fields of study.

\section{Methods and Procedures}

\subsection{The Sample}

A total of two hundred business students were selected for the present study. The researchers opted for this sample size because it was believed to be enough to get reliable results.

The sample subjects were divided on the basis of a number of sociolinguistic variables since investigating the influence of these variables on the criteria of acceptability was one of the objectives of the present study. Thus, the questionnaire of the present study included these variables as shown in. These variables were: gender, university affiliation, and specialization. Gender may play a vital role in the process of Arabicization. The justification of including gender variable in this study was because many studies suggested that females had different attitudes toward using Arabic. They may tend not to accept Arabicized terms and they may prefer English terms more than Arabic ones. University affiliation variable was included in the present study because the medium of instruction may have influence on the results of the study. The medium of instruction at the University of Jordan is English and Arabic. There are courses in English and others in Arabic. However, Yarmouk University's medium of instruction in all courses is English. The specialization variable was included because the students' different business background may affect the results of the study.

\subsection{Instrument of Data Collection}

\subsubsection{The Questionnaire}

The instrument that was employed in the present study was a questionnaire. This instrument was chosen because it is one of the most feasible ways to get valid and reliable results.

Cronbach's Alpha was used to test the reliability of the scale in the questionnaire. It was found that Alpha $(\alpha)$ was 0.959 which was a sign of a very high level of internal consistency. This proved the reliability of the questionnaire. It showed that the questions in the questionnaire reliably measured the extent of acceptability of the Arabicized business terms and the attitudes of business students toward the idea of Arabicization and Arabicized business terms, leading to reliable results. The questionnaire was based on AL-Abed AL-Haq (1998a), modified, and implemented in many previous studies such as (Al-Smadi, 1997; Diknash, 1998; O'kour, 1999; Halloush, 2000; Mahasneh, 2002) and many others. It consisted of four sections.

The first section aimed at collecting personal information of the subjects. This information represented the sociolinguistic background of the respondent. They were: gender, university affiliation, and specialization. The second section consisted of fifty English business terms accompanied by their Arabicized equivalents i.e., forty one terms were taken from different Arabic and Arabicized sources and nine terms were taken from the official website of the Jordan Academy of Arabic. The academy Arabicized only nine business terms. These nine terms

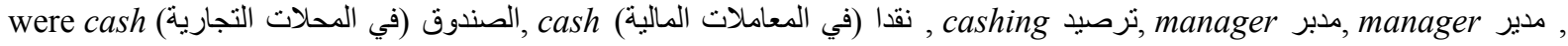

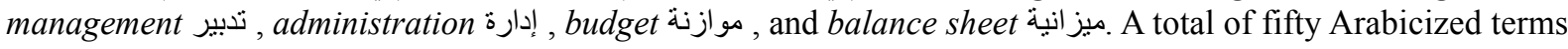
were evaluated by business students UJ and YU depending on the criteria of acceptability suggested by Cooper (1989, pp. 61-62):

1) Knowledge: indicates whether the respondent knows the Arabicized term or not. It also reveals whether the respondent has heard it before or not. 
2) Evaluation: is the extent of accepting the Arabicized equivalent of the English term by the respondent. Besides, it is concerned with the extent of considering this Arabicized equivalent as a good one.

3) Usage: refers to the frequency of using the Arabicized term by the respondent.

4) Proficiency: shows the ability of the respondent to utilize the Arabicized term within the correct context accurately.

5) Adoption: is the use of an Arabicized term consistently, repetitively and acceptably.

Each criterion of acceptability was tested using a five-point Likert scale. The minimum point in this scale was (1) while (5) was the maximum one. Number (1) stood for strongly disagree while (5) was strongly agree.

The third section (items 1-12) examined the attitude of business students toward Arabicization. The fourth section consisted of four questions. Question thirteen was intended to investigate the respondent's evaluation of the work of the Jordan Academy of Arabic in the Arabicization of business terms. The aim of question fourteen was to get the subjects' proposed procedures for the academy to be followed in the process of Arabicization of English business terms. Finally, the last two questions (15-16) were about the subjects' understandability of the questionnaire and the accuracy of their responses in the questionnaire. Copies of the questionnaire were distributed to two hundred business students at the University of Jordan and Yarmouk University. Then, the copies of the questionnaire were collected and the data were analyzed.

\subsection{Data Analysis}

The two hundred copies of the questionnaire were collected and using Statistical Package for the Social Sciences (SPSS), the data were analyzed after being classified. Moreover, the five-point Likert scale was used. The low range of means showed strong objection. On the contrary, the high range of means showed weak objection. For the purpose of measuring the variances in responses with the change of the variables, ANOVA and T-Test were used.

\section{Results and Discussion}

The central issue of the study was to measure the extent of acceptability of the Arabicized business terms, the extent in which the five criteria of acceptability (knowledge, usage, evaluation, adoption, and proficiency) were influenced by gender, university affiliation, and specialization. The purpose of the present study was also to understand the attitudes of business students toward the idea of Arabicization and the work of the Jordan Academy of Arabic.

The present section is divided into four main subsections. The title of the first one is "Acceptability of Arabicized Business Terms". The second subsection aims to show and discuss the attitudes of business students toward the idea of Arabicization. The evaluation of the work of the Jordan Academy of Arabic by the students is outlined in the third section. In the final subsection, the understandability of the questionnaire by the students is provided.

\subsection{Acceptability of Arabicized Business Terms}

Knowledge, evaluation, usage, proficiency and adoption were the criteria used to measure the extent of acceptability of the Arabicized business terms. The extent of acceptability was the means of the responses of the aforementioned criteria for every business term. Depending on a five-point Likert scale, the extent of acceptability for every Arabicized business term in every criterion of acceptability was interpreted as very low (1.00 to 1.49$)$, low (1.50 to 2.49), moderate (2.50 to 3.49), high (3.50 to 4.49), very high (4.50 to 5.00). The same scale was applied on the findings related to the five criteria of acceptability and to the findings related to the extent of acceptability of every business term.

The mean of every criterion for every term is shown in Table 1 . The overall average (extent of acceptability) for every term is also provided in the table. The table also provides the average mean for every criterion of the fifty terms. 
Table 1 . The acceptability of Arabicized business terms

\begin{tabular}{|c|c|c|c|c|c|c|c|c|}
\hline No & English Term & Arabic Term & $\begin{array}{l}\text { Knowledge } \\
\text { (Mean) }\end{array}$ & $\begin{array}{l}\text { Evaluation } \\
\text { (Mean) }\end{array}$ & $\begin{array}{l}\text { Usage } \\
\text { (Mean) }\end{array}$ & $\begin{array}{l}\text { Proficiency } \\
\text { (Mean) }\end{array}$ & $\begin{array}{l}\text { Adoption } \\
\text { (Mean) }\end{array}$ & $\begin{array}{l}\text { Extent of } \\
\text { Acceptability }\end{array}$ \\
\hline 1 & Absorptive capacity & الطاقة الاستيعابية & 2.780 & 2.770 & 2.950 & 2.905 & 2.725 & 2.85125 \\
\hline 2 & Abstract of a patent & ملخص براءة & 3.355 & 2.825 & 2.885 & 2.825 & 2.760 & 2.9725 \\
\hline 3 & Abstract of bank funds & ملخص أرصدة في & 3.180 & 2.870 & 2.685 & 2.815 & 2.675 & 2.8857 \\
\hline 4 & Abusive tax shelter & التلاعب بالسقف & 2.710 & 2.685 & 2.675 & 2.625 & 2.420 & 2.67375 \\
\hline 5 & Acceleration of maturity & استعجال مو عد السداد & 3.140 & 2.995 & 2.790 & 3.190 & 2.880 & 3.02875 \\
\hline 6 & Account deactivation & ت تقييد الحساب & 3.265 & 3.035 & 2.628 & 2.945 & 2.805 & 2.968711 \\
\hline 7 & Cash & $\begin{array}{l}\text { المحلات التجارية) } \\
\text { الصندوق }\end{array}$ & 3.755 & 3.060 & 2.790 & 3.050 & 2.995 & 3.16375 \\
\hline 8 & Cash & نقدا (في المعاملات & 3.770 & 3.120 & 2.945 & 3.145 & 3.130 & 3.245 \\
\hline 9 & Cashing & ترصيد & 3.500 & 3.205 & 2.915 & 3.085 & 2.920 & 3.17625 \\
\hline 10 & Credit worthiness appraisal & تقدير الملاءة & 2.410 & 2.780 & 2.390 & 2.470 & 2.265 & 2.5125 \\
\hline 11 & Endorser & المجيِّر & 2.395 & 2.305 & 2.640 & 2.440 & 2.410 & 2.445 \\
\hline 12 & Clearing agreement & اتفاقية مقاصة & 2.570 & 2.495 & 2.730 & 2.535 & 2.175 & 2.5825 \\
\hline 13 & Porterage & أجرة العتالة & 2.655 & 2.645 & 2.875 & 2.775 & 2.680 & 2.7375 \\
\hline 14 & Oligopoly & احتكار القلة & 2.985 & 3.010 & 3.200 & 3.010 & 2.790 & 3.05125 \\
\hline 15 & Annuitant & 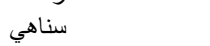 & 2.305 & 2.465 & 2.495 & 2.385 & 2.285 & 2.4125 \\
\hline 16 & Watered stock & أسهر مميهة & 2.288 & 2.409 & 2.462 & 2.381 & 2.270 & 2.384518 \\
\hline 17 & Bond amortization & اطفاء السند & 2.503 & 2.462 & 2.543 & 2.400 & 2.140 & 2.476671 \\
\hline 18 & Liability for endorsement & التزام النظهير & 2.585 & 2.305 & 2.540 & 2.285 & 2.315 & 2.42875 \\
\hline 19 & Compensatory balance & الرصيد المجزي & 2.500 & 2.510 & 2.715 & 2.465 & 2.580 & 2.5475 \\
\hline 20 & Gray market & السوق الغبراء & 2.180 & 2.385 & 2.568 & 2.535 & 2.360 & 2.416771 \\
\hline 21 & Manager & مدبر & 2.995 & 2.965 & 2.990 & 2.955 & 2.915 & 2.97625 \\
\hline 22 & Manager & 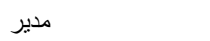 & 3.305 & 3.465 & 3.180 & 3.460 & 3.420 & 3.3525 \\
\hline 23 & Management & 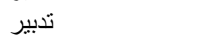 & 3.140 & 3.290 & 2.890 & 3.040 & 3.200 & 3.09 \\
\hline 24 & Administration & 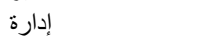 & 3.315 & 3.460 & 3.185 & 3.300 & 3.425 & 3.315 \\
\hline 25 & Interim financial statements & بيانات مالية مرحلية & 2.735 & 2.885 & 2.735 & 2.595 & 2.545 & 2.7375 \\
\hline 26 & Depreciation & الال المتلاك & 3.021 & 3.111 & 3.057 & 3.000 & 2.926 & 3.04712 \\
\hline 27 & Adjusted trial balance & ميز ان المراجعة & 2.807 & 3.254 & 2.990 & 3.180 & 2.895 & 3.058008 \\
\hline 28 & Non-current liabilities & الالالتز امات غير & 3.055 & 3.285 & 2.980 & 3.070 & 2.765 & 3.0975 \\
\hline 29 & Purchase allowances & مسموحات المشتريات & 3.150 & 3.180 & 3.005 & 3.300 & 3.055 & 3.15875 \\
\hline 30 & Contra revenue account & حساب مقابل للإِير اد & 2.985 & 2.905 & 2.744 & 2.754 & 2.764 & 2.846734 \\
\hline 31 & Consigned goods & بضاعة الأمانة & 3.055 & 2.935 & 2.700 & 2.900 & 2.740 & 2.8975 \\
\hline 32 & Cash receipts controls & رقابة المتحصلات & 2.715 & 2.725 & 2.785 & 2.630 & 2.620 & 2.71375 \\
\hline 33 & Bank reconciliation & مذكرة تسوية البنك & 2.940 & 2.805 & 2.865 & 2.700 & 2.630 & 2.8275 \\
\hline 34 & Supplies expenses & مصروفات اللوازم & 3.010 & 2.800 & 2.895 & 2.715 & 2.555 & 2.855 \\
\hline 35 & Transactions & العمليات المالية & 3.380 & 3.317 & 3.100 & 3.215 & 3.246 & 3.252816 \\
\hline 36 & Budget & 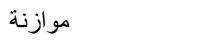 & 3.258 & 3.315 & 2.919 & 3.111 & 3.010 & 3.151134 \\
\hline 37 & Balance sheet & 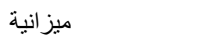 & 3.395 & 3.405 & 3.111 & 3.125 & 3.185 & 3.259074 \\
\hline 38 & Labor relations & العلاقات العمالية & 3.170 & 2.874 & 2.765 & 2.720 & 2.628 & 2.882353 \\
\hline 39 & Charts of accounts & الدليل المحاسبي & 2.850 & 2.730 & 2.725 & 2.754 & 2.475 & 2.764706 \\
\hline 40 & Capitalized value & القيمة المرسملة & 2.695 & 2.680 & 2.720 & 2.565 & 2.480 & 2.665 \\
\hline 41 & Shift premium & علاوة الدوريات & 2.495 & 2.490 & 2.520 & 2.480 & 2.460 & 2.49625 \\
\hline 42 & Time wages & الاجر حسب الساعة & 3.101 & 3.165 & 3.241 & 3.206 & 2.980 & 3.178168 \\
\hline 43 & Underwriting & الضمانات السندية & 3.040 & 2.830 & 2.745 & 2.910 & 2.640 & 2.88125 \\
\hline 44 & $\begin{array}{l}\text { Commercial credit } \\
\text { companies }\end{array}$ & شركات التقسيط & 2.990 & 2.795 & 2.765 & 2.965 & 2.730 & 2.87875 \\
\hline 45 & Functional middlemen & الوسطاء الوظيفيون & 2.770 & 2.705 & 2.680 & 2.595 & 2.585 & 2.6875 \\
\hline 46 & Standardization and grading & التدريج و التماثل & 2.425 & 2.305 & 2.535 & 2.391 & 2.340 & 2.413836 \\
\hline 47 & Partnership & شركة التضامن & 2.910 & 2.945 & 2.935 & 2.910 & 2.900 & 2.925 \\
\hline 48 & Commercial draft & السحب التجاري & 2.875 & 2.745 & 2.695 & 2.580 & 2.625 & 2.72375 \\
\hline 49 & Preferred stock & الاسهم الممتازة & 3.065 & 3.085 & 3.005 & 3.020 & 3.100 & 3.04375 \\
\hline \multirow[t]{2}{*}{50} & Current liabilities & الخصوم الجارية & 3.030 & 3.270 & 2.995 & 3.190 & 3.075 & 3.12125 \\
\hline & Average Mean & & 2.9303 & 2.8809 & 2.8177 & 2.8321 & 2.7299 & 2.8381 \\
\hline
\end{tabular}




\subsubsection{Criteria of Acceptability}

Every criterion will be discussed separately.

a) Knowledge: The average mean for this criterion was 2.9303. This revealed that this criterion fell in moderate level. This indicated that the majority of the students were familiar with the Arabicized terms in their field of study but there were still others who did not have knowledge of these terms.

b) Evaluation: The average mean for this criterion was 2.8809. Like knowledge criterion, evaluation criterion was ranked in moderate level. This showed a moderate extent of acceptance of the Arabicized equivalents of the English terms by the students.

c) Usage: The mean average of this criterion was 2.8177 . This value revealed a moderate frequency in using the Arabicized business terms by the students among themselves and with their professors.

d) Proficiency: The average mean for the fifty terms was 2.8321. This showed a moderate ability of the business students in utilizing the Arabicized business terms within the correct context accurately.

e) Adoption: Table 1 shows that the average means for this criterion for the fifty terms. It was 2.7299 . This criterion revealed the use of the Arabicized terms consistently, repetitively and acceptably. For the average mean for this criterion fell in the moderate level, it could be said that the students' way of using the Arabicized business terms was nearly consistent, repetitive and accepted. It was noted that the average for this criterion of the fifty terms was the lowest one among other criteria of acceptability.

By discussing the average mean of the five criteria for the fifty terms separately, it could be noticed that every criterion of acceptability affected the other. All of the overall averages of them fell in the moderate level and their values of means were very near to each others.

\subsubsection{Extent of Acceptability}

Investigating the extent of acceptability of the Arabicized business terms among the students was one of the main goals of the present study. The extent of acceptability of all of the fifty terms was 2.8381 . This indicated that the students moderately accepted these Arabicized business terms. It also shed light on the role of the Jordan Academy of Arabic in increasing the extent of acceptability of the Arabicized business terms among the students. The role of the academy needs to be enhanced to increase the extent of acceptability to be in high level.

According to Table 1 the term with the highest extent of acceptability in relation to others was (manager: مدير) followed by (administration: إدارة) and (balance sheet: ميزانية). The term with the lowest extent of acceptability in

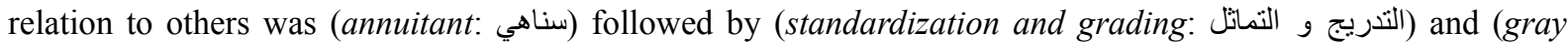
market: السوق الغبراء). Thus, it could be noticed that the term (manager: مدير) was the most accepted term among others. On the contrary, the term (Annuitant: سناهي) was the lowest accepted term among the fifty terms. Thus, it could be said that the term (Annuitant: سناهي) should be Arabicized again, taking into consideration the role of the users (students) in the process of Arabicization to produce an acceptable term.

The majority of the terms which constituted $84 \%$ were in the moderate level of acceptability and $16 \%$ of the terms were in the low level. It was noticed that there were no terms in the highest, high, and lowest levels. Thus, it could be said that the majority of the students were aware of these terms and only few of them did not know them. Moreover, these results indicated that the students considered the majority of these Arabicized terms as good equivalents for the English terms. Additionally, the students used and adopted these Arabicized terms moderately with a moderate ability to utilize them in correct context. Accordingly, more is required to increase the students' awareness of these terms and to raise their ability and frequency of using them in correct contexts consistently. First and foremost, their evaluation of these Arabicized terms should also be raised.

\subsubsection{Correlation between Sociolinguistic Variables and the Criteria of Acceptability}

The aim of this section is to show the correlation between the sociolinguistic variables, namely, gender, university affiliation and specialization, and the criteria of acceptability.

It was found that the male students' extent of acceptability of Arabicized equivalents of English terms was higher than female students' acceptability. Female's students tend to use English terms more than male's students. This reveals the role of gender in Arabicization. Regarding university affiliation variable, the mean of the all criteria of acceptability for YU was higher than the UJ's, except for proficiency criterion. Thus, the Jordan Academy of Arabic should pay more attention to UJ's students when publishing a pamphlet for business terms in the future. As for specialization variable, the highest extent of acceptability was scored by Management Information System (MIS). Islamic Banking got the lowest mean. 
To be more precise regarding the correlation between the sociolinguistic variable given in the present study and the criteria of acceptability mentioned previously, ANOVA and T-Test were run on every criterion of acceptability and every sociolinguistic variable given in the present study.

As for specialization variable, there was no significant correlation found between the criteria of acceptability and specialization variable. Regarding gender variable, there was a significant correlation between knowledge, evaluation, and usage and gender variable. The means for these three criteria for male students were higher than the means for female students. This indicated that male students were aware of the Arabicized equivalents for these fifty English terms more than female students. Also, male students considered these Arabicized equivalents for these fifty English terms as good ones more than female students did. Besides, male students' usage frequency of these Arabicized equivalents was higher than female students'. This result could be a pointer for the Jordan Academy of Arabic to take into consideration gender role in Arabicization process.

University affiliation variable had an influence on evaluation criterion. The mean for this criterion in YU was higher than in UJ. This showed that the students at YU considered that these Arabicized equivalents of these fifty business terms were good ones more than the students at UJ did. Depending on the results, the Jordan Academy of Arabic should take into consideration cooperating more with UJ's administration in the Arabicization process of business terms to raise evaluation criterion among the students at UJ. As for proficiency criterion, the results showed that there was a significant difference in responses among the students with the change of university affiliation variable. The ability of UJ's students to utilize these fifty Arabicized terms within correct contexts accurately was higher than the ability of YU's students. The reason behind this result will be explained in the next section.

\subsection{Attitudinal Trends toward Arabicized Terms}

This subsection aims at investigating the students' attitude toward the idea of Arabicization and Arabicized business terms. The students' responses to the twelve statements in the third section of the questionnaire were statistically analyzed. Five-point Likert scale was used by the students in their responses to the statements. Table 2 shows the mean of students' responses for every statement. Additionally, the table also demonstrates the average mean for all responses of the statements by the students. This value revealed the overall students' attitude toward the idea of Arabicization. Responses were interpreted as follows:

1) Strongly disagree (means from 1 to 1.49 ).

2) Disagree (means from 1.50 to 2.49 ).

3) Not sure (means from 2.50 to 3.49 ).

4) Agree (means from 3.50 to 4.49).

5) Strongly agree (means from 4.50 to 5.00 ).

Table 2. The attitudes toward Arabicization

\begin{tabular}{|c|c|c|}
\hline No. & Statement & Mean \\
\hline 1 & My self-confidence increases when using Arabicized business terms. & 3.150 \\
\hline 2 & My belonging to Arabic language is the motive to accept Arabicized business terms. & 3.520 \\
\hline 3 & $\begin{array}{l}\text { I think that The Arabicized business terms are better than the English business terms regarding the } \\
\text { transformation of ideas and information. }\end{array}$ & 3.025 \\
\hline 4 & $\begin{array}{l}\text { I think that Arabicized business terms facilitate the interactive communication with my colleagues and } \\
\text { professors at the department. }\end{array}$ & 3.355 \\
\hline 5 & I think that unifying the Arabicized business terms helps in spreading them in the Arab World. & 3.540 \\
\hline 6 & I think that the shorter the syllables are for the Arabicized business terms the more they become distributed. & 3.490 \\
\hline 7 & I think that the Arabicized business terms are clear and precise. & 3.165 \\
\hline 8 & I think that some of the Arabicized business terms need to be developed and rephrased. & 3.590 \\
\hline 9 & My colleagues respect me when using Arabicized business terms. & 3.075 \\
\hline 10 & $\begin{array}{l}\text { I think that The Arabicized business terms help the Arabic language to cope with the developments in the } \\
\text { contemporary life. }\end{array}$ & 3.305 \\
\hline 11 & In my discussions with my friends, I frequently use the Arabicized business terms. & 2.980 \\
\hline \multirow[t]{2}{*}{12} & I am seeking to spread and develop the Arabicized business terms. & 3.035 \\
\hline & Average Mean & 3.2692 \\
\hline
\end{tabular}


The enthusiasm toward the idea of Arabicization because of pan-Arab identity was strong. This appeared in the second statement. The students also agreed that unifying Arabicized business terms would help in distributing them in the Arab World as it appeared in the fifth statement. Nevertheless, they were not sure about the accuracy and the clearness of the Arabicized business terms. This was revealed in the seventh statement. The lowest mean among these statements was for the eleventh statement. Its mean fell in the third level "not sure". This indicated that the students were not sure about the frequency of using the Arabicized business terms among them. The mean of this statement, which was about to hit the low level (disagree), indicated that the students' attitude toward the usage of these terms with their colleagues was not sufficient and it should be improved a lot to be in the high level (agree). The reason behind this result was the students' agreement on the need for rephrasing and developing some of Arabicized business terms as it appeared in the eighth statement. The first, fourth and ninth statements were related to the issue of the use of the Arabicized business terms in students' communication. All of the means of these statements were in the moderate level (not sure). The students were not sure if the Arabicized business terms would make it easy for them to communicate with their colleagues and professors. They were also unsure if they would be self-confident and if they would be respected by their colleagues when using the Arabicized business terms. This appeared in item one and nine respectively. As for the spread of the Arabicized business terms, the students were uncertain if they were contributing in spreading the Arabicized business terms and developing them. This was obvious in the last statement. Moreover, they were unsure if the number of syllables of the Arabicized business terms was contributing in that. This was clear in the sixth statement. They were also unsure if the Arabicized business terms were better than the English terms in transferring the ideas and information and if these Arabicized terms would help Arabic language in coping up with the developments in the world.

Overall, the mean average for all of these statements was 3.2692, as shown in Table 2. This could be as evidence that the attitude of the students toward the idea of Arabicization of business terms was generally moderate. This indicated that the majority of the students had a positive attitude toward the idea of Arabicization of business terms and few of them had a negative attitude. It also showed that the majority of the students were aware of the process of Arabicization and the steps needed to be taken into consideration when distributing the Arabicized business terms and making them acceptable by the students. Furthermore, this implied that the students were willing to use the Arabicized business terms.

In order to end this section, ANOVA and T-Test were run on the data of this section to understand the influence of the sociolinguistic variables (gender, university affiliation and specialization) on the students' responses of the statements of this section.

It was found that gender had a role in responding to the sixth statement. Female students highly thought that the brevity of the term had an important role in spreading the Arabicized business terms in the Arab world. The mean of this statement for females was 3.718. This number fell in the high level (agree). However, the mean of responses to this statement for male students was 3.211 which fell in the moderate level (not sure). This result could help the Jordan Academy of Arabic in increasing the means of knowledge, evaluation and usage of the Arabicized business terms for female students by reducing the number of syllables of the Arabicized business terms (See Subsection 4.1.3 where the results revealed that there was a significant difference in responses due to gender).

There was a significant difference in responding to the fifth, sixth and eighth statements due to the change of university affiliation variable. The means of the responses of these statements for UJ's students fell in the high level (agree). They were 3.780, 3.860, and 3.920 respectively. However, the means of the responses of these statements for YU's students fell in the moderate level (not sure). They were 3.300, 3.120, and 3.260 respectively. These results indicated that UJ's students agreed that reducing the syllables of the Arabicized business terms and unifying them would help in distributing them in the Arab world. They also agreed that some of the Arabicized business terms should be restructured and developed. These thoughts could be the reasons which drove UJ's business students not to consider the Arabicized equivalents of the fifty English terms in this study as good equivalents as the same degree as YU's students did (See Subsection 4.1.3).

As for the ninth statement, there was a significant difference in responding to it with the change of university affiliation variable. Students at UJ respect each other when using Arabicized terms. The students' proficiency at UJ, as shown in Subsection 4.1.3 was higher than YU's. The ninth statement is the explanation behind this result. Since the students at UJ respect each other when using Arabicized terms in their communication, their ability to use these terms within correct contexts accurately will be enhanced.

Regarding the specialization variable, ANOVA test revealed that there was a significant difference in responding to sixth and eighth statements. Economics, Public Administrations, Islamic Banking and Finance students highly thought that the brevity of the Arabicized business terms would help in their spreading in the Arab World. 
Marketing, Finance and Banking Sciences, Economics, Islamic Banking and Finance students agreed that some of the Arabicized business terms should be restructured and developed. To spread the Arabicized business terms among these specializations, the Jordan Academy of Arabic should take the issue of brevity of the terms into consideration in the process of Arabicization. They also should try to develop and restructure some of these Arabicized terms and not to publish them as they are when producing a separate pamphlet for Arabicized terms in business field in the future.

\subsection{Evaluation of the Work of the Jordan Academy of Arabic}

The Jordan Academy of Arabic has not published a separate pamphlet for Arabicized business terms yet. This reveals the poor role of the academy in the Arabicization of terms in business fields.

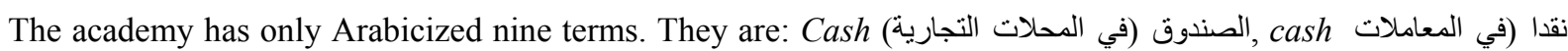

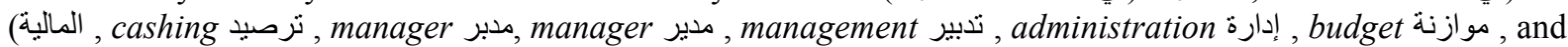
balance sheet ميز انية. As in Table 1 the extent of acceptability of these terms was 3.1921. This value fell in the moderate level. This indicated that the Arabicized business terms produced by the academy were moderately accepted by the business students.

However, these terms only constitute $18 \%$ of the fifty terms given in this study. Besides, these terms are not unified. For example, manager has two meanings. They are (مدبر) or (مدير).

For this poor role played by the Jordan Academy of Arabic, an open question was included in the questionnaire in an attempt to understand why the academy is lagging far behind this issue in business field as students thought.

Many of them believed that the failure of those who were responsible for following up the process of Arabicization was one of the reasons behind this poor status. They also thought that the scarcity of translators and researchers in this field was one of the causes of this condition. Moreover, they considered that non-unified terms led to this and the continuous and rapid developments in business field could be an obstacle in front of the academy in producing acceptable terms.

\subsection{Understandability of the Questionnaire}

In order to measure the understandability of the questionnaire to show the degree of the reliability of its results and the extent of the accuracy of its conclusions, two questions were included in the last section of the questionnaire. The questions were: Did you understand the questionnaire? And do you consider your answers as being accurate?

The results showed that $49.5 \%$ of the students understood the questionnaire very highly and $22.5 \%$ understood it highly. As for the accuracy level of the students' responses to the questionnaire, $56 \%$ of the students' responses were very highly accurate and $18.5 \%$ of their responses were highly accurate. This indicated that the majority of the students understood the questionnaire and answered it accurately, leading to correct and reliable results. This test of reliability was also supported by another one mentioned in Section Three called Cronbach's Alpha which revealed highly reliable results of the questionnaire (See Subsection 3.2.1).

\section{Conclusions}

The results of this study revealed the following conclusions regarding the five criteria of acceptability:

1) Arabicized business terms were moderately familiar to their users.

2) The extent of acceptability of the Arabicized equivalents of English business terms and the frequency of using them were moderate.

3) The ability of users to utilize Arabicized equivalents for English business terms was generally fair.

4) The users' way in using the Arabicized business terms was somewhat consistent, repetitive and acceptable.

5) Gender and university affiliation variables produced significant differences among users concerning the five criteria of acceptability. There was a correlation between gender and the criteria of acceptability, namely knowledge, evaluation and usage. Besides, there was a correlation between university and the criteria of acceptability, specifically evaluation and proficiency criteria.

The conclusions regarding the extent of acceptability of the Arabicized business terms by their users are as follows:

1) Generally, the Arabicized equivalents of the English business terms were moderately accepted by the users.

2) Overall, gender, university affiliation, and specialization did not cause differences among users regarding the moderate extent of acceptability of Arabicized business terms.

The following points summarize the main findings regarding the attitudinal trends of the users toward the idea of 
Arabicization and the Arabicization of business terms:

1) The enthusiasm among the users toward the idea of Arabicization because of pan-Arab identity was very strong.

2) Unifying Arabicized business terms would help in spreading them in the Arab World.

3) The Arabicized business terms should be rephrased and developed.

4) Overall, the users' attitude toward the Arabicized business terms was somewhat positive.

5) Students at UJ respect each other when using Arabicized business terms in their communication.

6) University affiliation and specialization variables caused significant differences regarding the issue of rephrasing and developing the Arabicized business terms. Like UJ's students, Marketing, Finance and Banking Sciences, Economics, Islamic Banking, and Finance students agreed that the Arabicized business terms should be restructured and developed.

7) UJ's students agreed that unifying the Arabicized business terms also would help in distributing them.

8) Females and UJ's students agreed that the brevity of the Arabicized business terms would help in distributing them in the Arab World. Correspondingly, Economics, Public Administration, Islamic Banking, and Finance students agreed with females and UJ's students regarding the issue of brevity.

The conclusions relating to the evaluation of the work of the Jordan Academy of Arabic are as follows:

1) The poor role of the academy was revealed through two main points:

a) The academy has not published a separate pamphlet for Arabicized business terms yet.

b) The academy published a very few number of Arabicized business terms and some of them are not unified, having two equivalents in Arabic for the same English term.

2) The reasons behind the failure of the Jordan Academy of Arabic from the users' point of view were as follows:

a) The scarce of translators and researchers in Arabicization issue in the field of business.

b) The existence of non-unified Arabicized business terms.

c) The failure in following-up the rapid and continuous developments in this field.

d) There is no coordination between the academy and the specialists in supporting the Arabicization process in business field.

This study is the first step towards enhancing the understanding of gender role in Arabicization process. This observation has many implications for research into gender role in the future. The present method could be applied to other sample and other field of study to enhance the terminology of Arabic language. This study could be a useful aid for decision makers in the Arabicization process to get acceptable Arabicized business terms in the future.

\section{References}

Abdelazeez, M. (1990). Alta'reeb fi alqadeem wa alhadeeth ma'a ma'ajem al'alfath almu'arrabah (In Arabic). Cairo: Dar alfikr al'arabi.

Abo Abdo, M. (1984). Atta'areeb wa mashakiloh (In Arabic). Rabat: Institute for Studies and Research on Arabization.

Abo Ghazaleh, T. (2001). Mu'jam Abo Ghazaleh lelmuhasabeh wala'mal (In Arabic). Beirut: Dar AL-Elm lelmalayeen.

AL-Abed AL-Haq, F. (1998a). Language planning and term planning: Criteria for accebt ability, Proceedings of the International Conference on Professional Communication and Knowledge Transfer. Terminology Work and Knowledge Transfer, 2, 2-19.

AL-Abed AL-Haq, F. (1998b). Toward a theoretical framework for the study of planning Arabicization. In A. Shunnaq, C. Dollerup, \& M. Saraireh (Eds.), Issues in Translation (pp. 53-68). Irbid National University and Jordanian Translators' Assosiation.

AL-Abed AL-Haq, F., \& Al-Masaeid, A. L. (2009). Islam and language planning in the Arab world: A case study in Jordan. Iranian Journal of Language Studies, 3(3), 267-302.

Al-Alami, E. (1990). Allughah al'arabiyah fi mwajahat atta'areeb: Mafhoom atta'areeb (In Arabic). AL-Lisan 
AL-Arabi, 34, 155-162.

Al-Assal, M., \& Smadi, O. (2012). Arabicization and Arabic expanding techniques used in science lectures in two Arab universities. Asian Perspectives in the Arts and Humanities, 2(1), 15-38. http://dx.doi.org/10.13185/AP2012.02103

Al-Baba, M. (1995). Atta'reeb bayn almadhi wa alhader (In Arabic). Atta'reeb (In Arabic), 5(10), 11-47.

Al-Didawi, M. (2007). Mafaheem attarjamah: Al-manthoor atta'areebi lenaql alma'arifah (In Arabic). Casablanca: Arab Cultural Centre.

Al-Hadidi, A., \& Hamad, A. (2010). Mulakhasat fi almuhasabah almaliyah: Alma'ayir aldawleyah le'dad attaqareer almaliyah (In Arabic). Amman: Central Press.

Al-Khuri, S. H. (2001). Dirasat fi attarjamah walmustalah watta'reeb (In Arabic). Damascus: Dar attali'a aljadidah.

Al-Maghribi, K. (1974). Almadkhal l'edarat ala'amal: Osos wa watha'ef (In Arabic). Amman: Jordan Press Foundation.

AL-Qahtani, S. H. (2000). Arabization in written discourse in Saudi Arabia. Doctoral dissertation, Ball State University, Muncie, Indiana, United States.

al-Qurashi, K. O. A. (1982). The feasibility of the Arabic language as medium of instruction in sciences. Doctoral dissertation, Indiana University, Indiana, United States.

AL-Sakran, L. S. (2004). Arabicization of agricultural terms from a terminology planning perspective. Master's thesis, Yarmouk University, Irbid, Jordan.

AL-Sayadi, M. (1980). Alta'areeb wa tanseequh fi alwatan alarabi (In Arabic). Beirut: Centre for Arab Unity Studies.

Al-Smadi, M. (1997). Language planning and Arabicization of military terms. Master's thesis, Yarmouk University, Irbid, Jordan.

Balasi, M. (1988). Alta'reeb: Bayn annathariyah wa attatbiq (In Arabic). Al-Mawqif Al-Adabi, 17(202, 203), $137-141$.

Cooper, R. (1989). Language planning and social change. Cambridge: Cambridge University Press.

Diknash, S. (1998). An evaluative study of the Arabicized nursing terms from a language planning perspective. Master's thesis, Yarmouk University, Irbid, Jordan.

El-Fadni, S. (2004). Arabicization in higher education: The case of medical colleges in The Sudan. Doctoral dissertation, University of Leicester, Leicester, England.

El-Khafaifi, H. M. (1985). The role of the Cairo Academy in coining Arabic scientific terminology: An historical and linguistic evaluation. Doctoral dissertation, The University of Utah, Salt Lake City, United States.

Emran, E. (1993). Elm almustalahat wa mashroo' lija'al al'arabiyah lughat al'oloom wa attiqaniyah (In Arabic). AL-Lisan AL-Arabi, (37), 169-174.

Farghal, M. (2012). Advanced issues in Arabic-English translation studies. Kuwait: Academic Publication Council-University of Kuwait.

Fowler, H. W., Fowler, F. G., \& Murray, J. A. H. (1919). The concise Oxford dictionary of current English. Oxford: The Clarendon Press.

Halloush, L. A. (2000). The Arabicization of medical terms in light of language and terminlogy planning. Master's thesis, Yarmouk University, Irbid, Jordan.

Hawamdeh, F. (2004). Term planning: A case study of weather terms. Master's thesis, Yarmouk University, Irbid, Jordan.

Jaied, W. M. (2010). Aspectos semánticos de la hipérbole en algunos textos Árabes traducidos al castellano. Doctoral dissertation, Universidad de Granada, Granada, Spain.

Khalifah, A. (1978). Allughah al'arabiyah wa atta'areeb fi al'asr alhadeeth (In Arabic). Amman: Jordan Academy of Arabic.

Mahasneh, B. (2002). Evaluation of the rendetions of internet terms into Arabic. Master's thesis, Yarmouk University, Irbid, Jordan. 
O’kour, E. (1999). Language planning and Arabicization of carpentry terms. Master's thesis, Yarmouk University, Irbid, Jordan.

Qoqazeh, M. (2013). The feasibility of Al-Lisan Al-Arabi journal's Arabicization of the ophthalmology terms. Master's thesis, Yarmouk University, Irbid, Jordan.

Rey, A. (1995). Essays on terminology (Vol. 9). Amesterdam/Philadelphia: John Benjamins Publishing Company. http://dx.doi.org/10.1075/btl.9

Sager, J. C. (1990). Practical course in terminology processing. Amsterdam: John Benjamins Publishing Company. http://dx.doi.org/10.1075/z.44

The International Information Centre for Terminology (2005). Guidelines for terminology policies: Formulating and implementing terminology policy in language communities. Paris, France.

\section{Copyrights}

Copyright for this article is retained by the author(s), with first publication rights granted to the journal.

This is an open-access article distributed under the terms and conditions of the Creative Commons Attribution license (http://creativecommons.org/licenses/by/3.0/). 